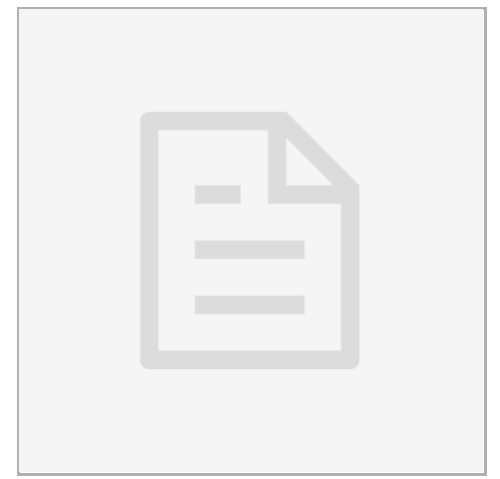

AUG 14, 2019

\section{open ठaccess}

\section{DOI:}

dx.doi.org/10.17504/protocol s.io.6cbhasn

\section{Protocol Citation: Natalie} Solonenko, Marie Burris 2019. DNA extraction for HMW DNA. protocols.io https://dx.doi.org/10.17504/p rotocols.io.6cbhasn

License: This is an open access protocol distributed under the terms of the Creative Commons Attribution License, which permits unrestricted use, distribution, and reproduction in any medium, provided the original author and source are credited

\section{Protocol status: Working} We use this protocol and it's working

Created: Aug 09, 2019

Last Modified: Oct 28, 2020

\section{PROTOCOL integer ID:} 26723

\section{(3) DNA extraction for HMW DNA}

\section{$\rightarrow$ In 1 collection}

Natalie

Solonenko ${ }^{1}, \quad$ Marie Burris ${ }^{1}$

${ }^{1}$ The Ohio State University Department of Microbiology

\section{Sullivan Lab Temperton Lab}

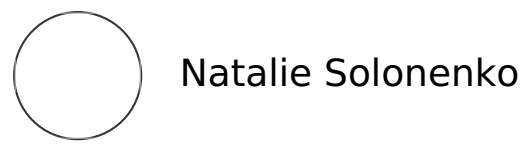

\section{ABSTRACT}

This protocol is intended for extraction of HMW DNA from bacterial or viral samples.

\section{GUIDELINES}

For mixing steps in this protocol, never mix by vortexing or pipettinig. Mix by inversion or gently flicking the tube.

\section{SAFETY WARNINGS}

(. This protocol uses phenol:chloroform and chloroform. Read the SDS for these reagents before starting and always use them in a fume hood.

\section{BEFORE START INSTRUCTIONS}

Ensure your sample is $500 u$ or less in volume.

\title{
Lyse cells/viruses
}

1 Add 600ul lysis buffer to less than $500 u$ of sample in a $2 \mathrm{~mL}$ tube. 
I $600 \mu \mathrm{L}$ lysis

buffer

Note

To make lysis buffer, add the following to $10 \mathrm{~mL}$ of $1 \mathrm{X} T \mathrm{TE}$ :

1. 300 ul $20 \%$ SDS

2. $60 \mathrm{ul} 20 \mathrm{mg} / \mathrm{mL}$ protK

1.1 Incubate $1 \mathrm{hr}$ at $37 \mathrm{C}$.

$\mathrm{f}^{\circ} 37^{\circ} \mathrm{C}$

(2) 01:00:00

\section{Extract DNA}

2 Add 1 vol phenol:chloroform and mix by inversion.

Safety information

Always work with phenol:chloroform in a fume hood.

2.1 Spin at max speed $5 \mathrm{~min}$ at RT.

(3) 00:05:00

$\AA^{\circ}$ Room temperature

2.2 Remove aqueous layer to new $2 \mathrm{~mL}$ tube.

3 Repeat step 2. 
$4 \quad$ Add 1 vol chloroform and mix by inversion.

\section{Safety information}

Always work with chloroform in a fume hood.

4.1 Remove aqueous layer to new $2 \mathrm{~mL}$ tube.

4.2 Spin at max speed 5 min at RT.

00:05:00

$8^{\circ}$ Room temperature

\section{Precipitate DNA}

5 Add ice cold absolute ethanol to fill tube (2.5-3 vol) and mix by inversion.

5.1 Incubate at $-20 \mathrm{C}$ for $>30 \mathrm{~min}$.

(3) $00: 30: 00$

$8^{\circ}-20^{\circ} \mathrm{C}$

Note

Shorter incubation time can be used, but is not recommended for low biomass samples.

The longer the incubation the more DNA will precipitate, but note that more salts will precipitate as well.

Spin at max speed for 15 min at 4 C. Remove and discard supernatant. 


\section{2}

\section{(3) 00:15:00}

$8^{\circ} 4{ }^{\circ} \mathrm{C}$

6 Rinse pellet with $1 \mathrm{~mL} \mathrm{RT} 70 \%$ ethanol.

I $1 \mathrm{~mL} 70 \%$

ethanol

6.1 Spin at max speed for 2 min.

00:02:00

$8^{\circ}$ Room temperature

6.2 Remove and discard supernatant.

$7 \quad$ Air dry DNA pellet.

Note

This can be done at room temperature, but will go faster at $40 \mathrm{C}$. Avoid over-drying the pellet as this will make it more difficult to resuspend.

\section{Resuspend DNA}

8 Resuspend DNA in 100ul warm nuclease-free water.

\section{I $100 \mu \mathrm{L}$ water}

\section{Note}

Do NOT vortex or pipet to resuspend. Gently flick the tube and leave at room temperature for up to 4 hours. Store at $4 \mathrm{C}$ overnight and flick again the next day. If your pellet is difficult to resuspend, incubate at $56 \mathrm{C}$ flicking periodically until the pellet dissolves. 
9 At this point you can check the concentration (we recommend Qubit) and purity (NanoDrop) of your DNA. Ensure the pellet is fully resuspended before you try. 